\title{
Kırsal Alanlarda Sosyo Ekonomik Yapı ve Yaşam Memnuniyeti: Aydın ilii Örneği
}

\author{
Fırat ASLAN ${ }^{* 1}$, Göksel ARMAĞAN² \\ ${ }^{1}$ Aydın Adnan Menderes Üniversitesi Fen Bilimleri Enstitüsü, Aydın \\ ${ }^{2}$ Aydın Adnan Menderes Üniversitesi Ziraat Fakültesi Tarım Ekonomisi Bölümü, Aydın
}

Öz: Bu araştırmanın amacı, Aydın ilinde tarımsal üretim yapan işletmelerin ekonomik sermaye unsurları incelenerek, üreticilerin yaşam memnuniyet düzeyini belirlemektir. Bu amaç dâhilinde araştırmada, Aydın iline bağı üç ilçe ve bu ilçelere bağlı 12 köyde toplam 96 adet tarımsal işletme, oransal örnek hacmi ile belirlenmiş ve veriler yüz yüze anket yoluyla toplanmışıı. Ayrıca dünya mutluluk endeksi yargılarından faydalanılarak, geliştirilen ölçek yardımı ile üretici yaşam memnuniyet düzeyi üç gruba ayrılmıştır. Bu üretici memnuniyet grupları; 1-3.02 arası ölçek düşük memnuniyet, 3.06-3.51 arası ölçek orta memnuniyet ve 3.56-5 arası ölçek ise yüksek memnuniyet düzeyi gruplarıdır. Araştırmada yapılan faktör analizine göre, yaşam memnuniyetine etki eden 14 ana değişken 4 faktörde toplanmıştır. Bu araştırmada sonuç olarak; ele alınan tarımsal işletmelerin ekonomik sermaye göstergeleri ile üreticilerin memnuniyet düzeyi arasındaki ilişki anlamlı çıkmamış olup sadece ilçeler arasında anlamlı bir ilişki çıkmıştır $(p<0.05)$. Çine ilçesindeki üreticilerin, Nazilli ve Söke ilçesindeki üreticilerden daha yüksek memnuniyet düzeyi grubunda yer aldığı saptanmıştır. Araştırmada, ekonomik sermaye unsurları ile yaşam memnuniyeti arasında bir ilişki bulunmadığından, bu durum ile ilgili paranın mutluluk getirmediğini söylemek mümkün olabilir.

Anahtar Kelimeler: kırsal kalkınma, kırsal mutluluk, mutluluk, sosyo-ekonomik analiz

\section{Socio-Economic Structure and Life Satisfaction in Rural Areas: The Case of Aydın}

Abstract: The aim of this research is to determine the life satisfaction level of producers by analyzing the economic capital elements of agricultural enterprises in Aydın. For this purpose, the data were collected with a stablished proportional sample size face to face survey of 96 agricultural holdings 12 villages of these in three districts of Aydin Province. In addition, using the scale developed with basis on world happiness index judgments, producer satisfaction level was divided into three categories. The scale of 1-3.02 is considered as low satisfaction, the scale of 3.06-3.51 is considered as medium satisfaction and the scale of 3.56-5 is considered as high satisfaction. According to the factor analysis conducted in the study, 14 variables affecting life satisfaction were grouped in four factors. As a result of this research; the relationship between the economic capital elements of agricultural holdings and producers' satisfaction level was not significant and a significant relationship was only found among districts. Producers in Çine district were found to be in a higher level of satisfaction than producers in Nazilli and Söke districts. In the research, since there is no relationship between economic capital elements and life satisfaction, it can be concluded that money does not bring happiness.

Keywords: rural development, rural happiness, happiness, socio-economic analysis

\section{GíRiş}

Sosyo ekonomik yapı: nüfus, gelir, ulaşım, eğitim, sağlık, işgücü, tarım, turizm, kültür, seçim ve adalet gibi önemli göstergelerin farklı biçimlerde kullanılıp bir araya gelmesiyle oluşan çok değişkenli bir kavram olarak tanımlanabilir. Sosyo ekonomik yapıdaki iyileşme ile kırsal alanlara sosyo ekonomik açıdan dinamizm kazandırma, sosyo politik istikrara katkıda bulunma, refah düzeyini yükseltici rol oynama ve yaşam memnuniyetini yükseltme bakımından sağladığı güç ile kırsal alanlara olumlu kazanımlar sağlayabilir (illhan, 2006). Birbirini yakından ilgilendiren yaşam memnuniyeti ve sosyo ekonomik yapı, kırsal alanların sürdürülebilirliğine büyük gelişmeler sağlamaktadır.

Kırsal alanların gelişimini ve sosyo ekonomik özelliklerini ilgilendiren yaşam memnuniyeti, ilk çağlardan bugüne kadar hep tartışılmakta olup felsefe, tıp, psikoloji, sosyoloji ve ekonomi gibi önemli bilimlerin üzerinde durduğu makro ekonomik bir göstergedir. Mutluluğun; demografik, ekonomik, fiziksel çevre, sosyal çevre ve içinde yaşanılan ülkenin sosyo-ekonomik durumu gibi değişkenlerin bileşimi sonucunda oluştuğunu belirtenlere göre, mutluluk ile yaşamdan alınan memnuniyet arasında büyük bir yakınlık söz konusudur (Şeker, 2010). Günümüz dünyasında mutluluk ile paralel kullanılan yaşam memnuniyeti; Türkiye dâhil olmak üzere birçok ülkede çok sayıda kişiye uygulanan iyi oluş, yaşam doyumu, tatmin olma ve memnuniyete yönelik anketlerle ölçülmektedir. Keleş ve ark. (2018) kırsal alandan sosyal sermayenin yaşam memnuniyeti üzerine yönelik yapmış oldukları çalışmalarında, yaşam memnuniyeti ile sosyal sermaye arasında pozitif yönlü bir etkileşim olduğunu bulmuşlardır. Mateu ve ark. (2020) Peru'da yoksul bölgelerde mutluluk ve yoksulluk arasındaki

Sorumlu Yazar: firatasIn-adu@hotmail.com. Bu çalışma yüksek lisans tez ürünüdür ve Aydın Adnan Menderes Üniversitesi Bilimsel Araştırma Projeleri Birimi tarafından desteklenmiştir (Proje No: ZRF-18018).

Geliş Tarihi: 26 Şubat 2020

Kabul Tarihi: 19 Haziran 2020 
ilişkiyi bulmak için en fakir beş bölgede yaşayan kişilere yönelik araştırmalarında geliştirdikleri ölçüm tekniklerinde, yoksulluk indeksinin yükselmesi, mutluluk düzeyini düşürdüğü sonucuna ulaşmışlardır. Katipoğlu ve Armağan (2020) araştırmalarında, tarımda beşeri ve sosyal sermayenin kırsal kalkınmada önemli olduğunu ve yaşam memnuniyetini etkileyen bazı sosyo ekonomik göstergeler ile sosyal sermaye arasında anlamlı ilişkiler olduğunu tespit etmişlerdir.

Tarımsal faaliyetlerin sürdürülebilir hale gelebilmesi için kırsal alanlardaki üreticilerin, sosyo ekonomik durumlarının ve yaşam memnuniyet düzeyinin rasyonel bir şekilde araştırılması gerekir. Bu tür çalışmaların yapılması, kırsal alanlarda yaşayan üreticilerin sorunlarının ve ihtiyaçlarının çözümünde olumlu gelişmeler doğurabilir. Easterlin (1974)'in çalışmasında dile getirdiği gibi, toplumun temel ihtiyaçlarının karşılandığı noktada hükümetlere önerisi, kişi başına mutluluğu artırmaları gerektiği yönündedir. Ura ve ark. (2012) araştırmalarında, Butan (Bhutan) ülkesinde mutluluk endeksini, 33 gösterge, 124 değişken ve 9 önemli faktörle bireylerin refahını ve mutluluğunu açıklamışlardır. Kentsel ve kırsal alanlarda yapılan bu araştırmaya göre, 2010 yılında Bhutan halkının \%8.3'ü çok mutlu, \%32.6'sı yoğun bir şekilde mutlu, \%48.7'si az mutlu ve \%10.4'ü ise mutsuz olduğu sonucuna varmışlardır. Kahneman ve Deaton (2010) ABD'de 450 bin kişi ile yapmış oldukları araştırmada yüksek gelir yaşam doyumunu sağlarken, mutluluğu satın alamaz; düşük gelir ise düşük yaşam memnuniyeti ve düşük mutluluğa neden olduğu sonucuna varmışlardır. Yaşam memnuniyeti ve sosyo ekonomik yapıyı doğrudan ilgilendiren gelirin yüksek olması mutluluğu etkilediğini görmekteyiz.

Tarımsal üretimin kendine özgü özellikleri nedeniyle tarım sektörünün desteklenmesinin gerektiği yaygın bir görüştür. íkinci dünya savaşından sonraki süreçlerde Avrupa Birliği ülkelerinde tarıma önemli destekler yapılmıştır. Bu desteklemelerin temel amacı tarımsal yapının iyileştirilmesine yöneliktir. Günümüze kadar olan süreçte Avrupa Birliği ülkelerinde, tarım sektörü gelişmesini fiyat desteklemelerine ve pazarı düzenleyen mekanizmalara borçludur. Ancak günümüzde Avrupa Birliğinde tarımdaki sosyo ekonomik yapı belli bir düzeye gelmiş olup, izlenen politikalarda tarımın çok fonksiyonluluğuna önem verildiği görülmektedir (Armağan ve ark., 2012). Yapılan tüm bu çalışmalar göz önüne alındığında, kırsal alanlarda yaşayan insanların yaşam memnuniyet düzeyi ve sosyo ekonomik özelliklerinin arttırılması, kırsal alanlara olumlu açıdan süreklilik sağlayacağı söylenebilir.

Kırsal alanlarda sürdürülebilir kalkınma bağlamında tarımı daha da verimli ve sürekli hale getirebilmek için tarımsal üreticilerin sosyo ekonomik yapısını geliştirmek ve memnuniyet düzeyini arttırabilmekle olabileceğidir. Bu araştırma ile kırsal alanlarda yaşayan üreticilerin ekonomik sermaye durumlarının ve yaşam memnuniyet düzeylerinin araştırılması, kırsal alanların sürekliliği açısından büyük bir önem taşıyacağı öngörülmektedir. Sürdürülebilir kırsal alanların gelişimini doğrudan ilgilendiren yaşam memnuniyeti ve sosyo ekonomik yapı, son yıllarda tüm dünyada önemli bir konu haline gelmiş olup birçok bilim dalının araştırma konusu olduğu söylenilebilir. Bu araştırmada, Aydın ilinde tarımsal faaliyette bulunan üreticilerin sosyo ekonomik özellikleri ile yaşam memnuniyet düzeyinin belirlenmesi ve aralarındaki ilişkilerin ortaya konması amaçlanmaktadır.

\section{MATERYAL VE YÖNTEM}

Araştırmanın ana materyalini, Aydın iline bağı üç ilçe ve bu ilçelere bağlı 12 köyde tarımsal üreticilerden elde edilen anket verileri oluşturmaktadır. Aydın ilinde 2016 yılında Çiftçi Kayıt Sistemi (ÇKS)'ye kayıtlı toplam 56 bin 502 üretici bulunmaktadır. Araştırmaya konu olan ilçeler Nazilli, Çine ve Söke ilçeleri olup tarımsal potansiyeli oldukça yüksek olan ilçelerdir.

Anket yapılacak üretici sayısının belirlenmesinde oransal örnek hacmi kullanılmıştır (Newbold, 1995). Bu formül aşağıdaki gibidir:

$$
n=\frac{N p(1-p)}{(N-1) \sigma_{p x}^{2}+p(1-p)}
$$

Bu formülde;

n: Örnek hacmini,

$\mathrm{N}$ : Aydın ilinde ÇKS'ye kayıtlı toplam çiftçi sayısını $(56,502)$

$\mathrm{p}$ : Yaşam memnuniyeti yüksek olan üreticilerin oranı (maksimum örnek hacmine ulaşmak için \%50 alınmıştır)

$\sigma_{\mathrm{p}}$ : Olasılık düzeyi güven aralığını (\%95 güven aralığı, 0.10 hata payı için $1.96 \sigma_{p}=0.10$ eşitliğinden, $\sigma_{p}=0.05102$ ) ifade etmektedir.

Yapılan hesaplanma sonucunda ise örnek hacmi 96 üretici olarak bulunmuştur. Araştırmaya dâhil olan ilçe ve ilçe köylerinde üretici sayısının diğer ilçelere göre yüksek olması, örnek köylerin gayeli olarak seçilip titizlikle dikkate alınması Aydın ilini temsil etme gayesi yüksek olduğu söylenebilir. Çine ilçesine bağlı Gökyaka, Akçaova, Topçam, Kasar, Söke ilçesine bağlı Sarıkemer Tuzburgazı, Bağarası, Sazlı, Nazilli ilçesine bağlı Aşağıyakacak, Pirlibey, Esenköy ve İsabeyli köylerinde sekizer çiftçi olmak üzere toplam 96 çiftçi ile Haziran-Ağustos 2018 tarihleri arasında yüz yüze görüşülerek soru formları uygulanmıştır.

Ele alınan tarımsal işletmeler, kırsal alanlarda yer almakta ve bu işletmeler aktif olarak bitkisel ve hayvansal üretim yapmaktadırlar. Üreticiler, brüt kâra göre \% $25^{\prime}$ lik dört gruba ayrılmıştır. Brüt karı; 64 bin 100 TL den az olan işletmeler 
birinci grup, 64 bin 101 TL ile 105 bin 400 TL arası ikinci 177 bin 901 TL ve üstü dördüncü grup olarak belirlenmiştir. Bu gruplar eşit bir şekilde 24'er üreticiden oluşmakta olup analizler toplam 96 üretici üzerinden yapılmıştır. Bu araştırmada tarımsal işletme sahiplerinin yaşam memnuniyet ve/veya mutluluk düzeyinin belirlenmesi amacıyla, Dünya Mutluluk Endeksinin kullandığı beşli likert ölçekli yargılar kullanılmıştır. Üreticilerin genel mutluluk durumu, Dünya Mutluluk Merkezinin kullandığı beşli likert ölçekli (1-Asla böyle hissetmiyorum, 2-Nadiren böyle hissediyorum, 3-Bazen böyle hissediyorum, 4-Sık sık böyle hissediyorum, 5-Her zaman böyle hissediyorum) 26 yargı kullanılarak belirlenmiştir (World Happiness Center, 2002). Ayrıca Türkiye İstatistik Kurumu (Tüik)'nun Yaşam Memnuniyeti Araştırması için kullandığı yargılar ve likert ölçekli sorular şu şekildedir: Üreticileri en çok mutlu eden kişilerin (1-Tüm aile, 2-Çocuklar, 3-Eş, 4-Anne/Baba, 5Kendisi 6- Torunlar) kim olduğu, en çok mutlu eden değerlerin (1-Güç, 2-Başarı, 3-İş, 4-Sağlık, 5-Sevgi, 6-Para, 7Diğer (ibadet, huzur vb.)) ne olduğu, Üreticilerin kamu hizmetlerinden memnuniyet durumu, beşli likert ölçekli (1Hiç memnun değilim, 2-Memnun değilim, 3-Kararsızım, 4Memnunum, 5-Çok memnunum) yargılar kullanılarak belirlenmiştir (TÜiK, 2013). Üreticilerin gelecekten beklenti ve umut düzeyi aynı şekilde beşli likert ölçekli (1-Hiç umutlu değilim, 2-Umutlu değilim, 3-Kararsızım, 4-Umutluyum 5Çok umutluyum) yargıları kullanılarak belirlenmiştir. Ele alınan tarımsal işletmelerin sosyo-ekonomik özellikleri ve Çizelge 1. Üreticilerin bazı sosyo ekonomik göstergeleri

\begin{tabular}{|c|c|c|c|c|c|}
\hline & $\begin{array}{l}\text { 1. Grup } \\
(n=24)\end{array}$ & $\begin{array}{l}\text { 2. Grup } \\
(n=24)\end{array}$ & $\begin{array}{l}\text { 3. Grup } \\
(n=24)\end{array}$ & $\begin{array}{l}\text { 4. Grup } \\
(n=24)\end{array}$ & $\begin{array}{l}\text { Genel } \\
(n=96)\end{array}$ \\
\hline \multicolumn{6}{|l|}{ İşletmelerin Nüfus Durumu } \\
\hline Erkek & $57(\% 55.9)$ & $51(\% 45.9)$ & $51(\% 48.6)$ & $62(55.4)$ & $221(\% 54.1)$ \\
\hline Kadın & $45(\% 44.1)$ & $60(\% 54.1)$ & $54(\% 51.4)$ & $50(44.6)$ & $209(\% 48,6)$ \\
\hline Üreticilerin Yaş Ortalaması (Yıl) & $\begin{array}{l}54.92 \\
(26.83)\end{array}$ & $\begin{array}{l}48.50 \\
(11.20)\end{array}$ & $\begin{array}{l}48.79 \\
(10.51)\end{array}$ & $\begin{array}{l}46.17 \\
(12.36)\end{array}$ & $\begin{array}{l}49.59 \\
(10.99)\end{array}$ \\
\hline $\begin{array}{l}\text { Üreticilerin Deneyim Ortalaması } \\
(Y, I)\end{array}$ & $\begin{array}{l}26.83 \\
(9.81)\end{array}$ & $\begin{array}{l}25.96 \\
(10.63)\end{array}$ & $\begin{array}{l}23.46 \\
(12.97)\end{array}$ & $\begin{array}{l}20.50 \\
(12.13)\end{array}$ & $\begin{array}{l}24.19 \\
(11.54)\end{array}$ \\
\hline \multicolumn{6}{|l|}{ Üreticilerin Öğrenim Durumu } \\
\hline Illköğretim & $20(\% 83.3)$ & $16(\% 66.7)$ & $19(\% 79.2)$ & $15(\% 62.5$ & $70(\% 72.9)$ \\
\hline Lise & $3(\% 12.5)$ & $6(\% 25.0)$ & $5(\% 20.8)$ & $6(\% 25.0)$ & $20(\% 20.8)$ \\
\hline Yüksekokul & $1(\% 4.2)$ & $2(\% 8.3)$ & $0(\% 0.0)$ & $3(15.5)$ & $6(\% 6.2)$ \\
\hline \multicolumn{6}{|l|}{ Üreticilerin Tarımsal Örgütlere } \\
\hline Üye Olanlar & $16(\% 66.7)$ & $18(\% 75.0$ & $18(\% 75.0)$ & $17(\% 70.8)$ & $69(\% 71.9)$ \\
\hline Üye Olmayanlar & $8(\% 33.3)$ & $6(\% 25.0)$ & $6(\% 25.0)$ & $7(\% 29.2)$ & $27(28.1)$ \\
\hline \multicolumn{5}{|l|}{ Üreticilerin Tarımsala Örgütlere } & \\
\hline Yönetici Olanlar & $1(\% 4.2)$ & $3(\% 12.5)$ & $0(\% .0)$ & $2(\% 8.3)$ & $6(\% 6.3)$ \\
\hline Yönetici Olmayanlar & $23(\% 95.8)$ & 21 (\%87.5) & $24(100.0)$ & 22 (\%91.7) & 18 (\%93.7) \\
\hline
\end{tabular}

grup, 105 bin 401 TL ile 177 bin 900 TL arası üçüncü grup, yaşam memnuniyet düzeyi verileri; yüzde dağılımları, basit tanımlayıc istatistikler yardımıyla bulunmuş olup verilere faktör analizi, Kruskall-Wallis ve Khi-Kare analizi uygulanmıştır

\section{BULGULAR}

İncelenen İşletmelerin Genel Özellikleri

Araştırma kapsamında ele alınan tarımsal işletmelerin genel özelliklerine ilişkin veriler gruplandırılmış biçimlerde aşağıdaki tablolarda detaylı bir şekilde verilmiştir. Bu işletmelerde; işletme sahiplerinin \%71.9'unun tarımsal örgütlere üye olduğu, \%6.3'ünün ise tarımsal örgütlerde yöneticilik yaptığı saptanmıştır (Çizelge 1 ).

Eğitim düzeyinin yüksek olması, farkındalığı daha çok artırmakta olup bilgiye ulaşmayı kolaylaştırmaktadır. İnsanlar bilgiyi kullanarak günlük yaşamında ihtiyaçlarını daha kolay gidermesi, insanı sosyo ekonomik açıdan tatmin ve memnun edebilir. Tarımsal işletme ortalamasına göre işletme sahiplerine ait arazi varlıklarının; \%74.17'sinin mülk arazisi, \%18.49'unun ortakçılığa tutulan arazi, \%7.33'ünün büyük bir oranı üreticilere ait olduğu söylenebilir (Çizelge 2).

Arazi, ekonomik bir gösterge olup hem tarımsal üretim, hem de önemli bir sermaye kaynağıdır. Özellikle tarımla geçimini sürdüren üreticilerin büyük bir çoğunluğu, tarımsal arazilerden gelirler elde etmektedirler. Geçimini tarımdan kira ve/veya ortakçılığa verilen arazisidir. İşletme arazinin

(Parantez içindeki rakamlar yüzde ve standart sapma değerlerini vermektedir) 
Çizelge 2. Ele alınan tarımsal işletmelerde ortalama arazi tasarruf şekli dağılımı ve varlığı

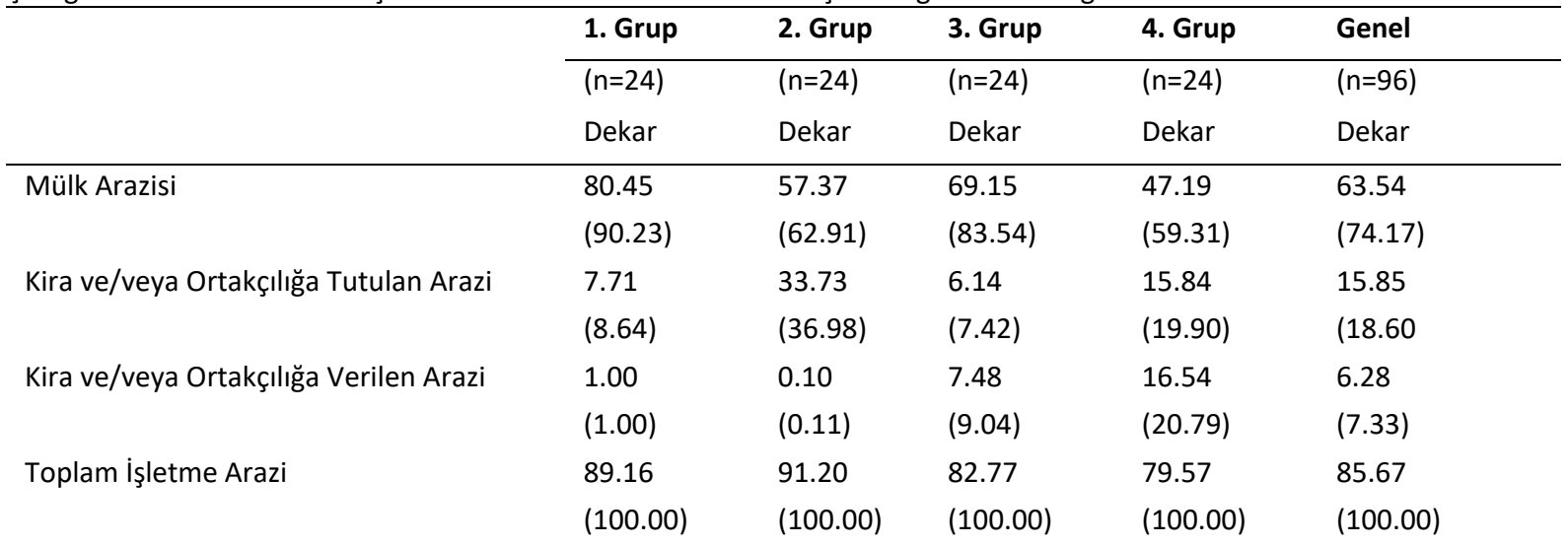

(Parantez içindeki rakamlar yüzde değerleri vermektedir)

sağlayan üreticiler için arazi varlığı ve sermayesi, yaşam memnuniyeti ve tatmin olma açısından büyük bir önem taşımaktadır. Yüksek gelire ve verime sahip tarımsal araziler daha da kıymetli olup üreticileri daha da memnun bırakmaktadır.

İncelenen Tarımsal İşletmelerde Üreticilerin Yaşam Memnuniyet Durumu

$\mathrm{Bu}$ araştırmada, kırsal alanlarda ele alınan tarımsal üreticilerin ekonomik sermaye yapıları ve yaşam memnuniyeti, detaylı bir şekilde analiz edilerek aşağıdaki çizelgelerde verilmiştir. Ele alınan tarımsal işletmelerde üreticilerin ortalama mutluluk düzeyine bakıldığında; ekonomik sermayesi düşük olan 1 gruptaki üreticilerin ortalama mutluluk düzeyleri 3.33 ölçek ile ekonomik sermayesi yüksek olan 4 gruptaki üreticilerinin 3.26'lık ölçek ortalamasından biraz daha yüksek çıktığı görünmektedir. Mutluluğun önemli göstergelerinden olan fiziksel, ruhsal ve duygusal yaşam yargıları da üretici grupları itibariyle değişiklik göstermiş olup işletme ortalamasına göre; 3.18 ortalamayla hayatım fiziksel olarak dengede, 2.56 ortalamayla hayatım duygusal olarak dengede, 2.54 ortalamayla hayatım ruhsal olarak dengede ortalaması mevcuttur. Yaşam memnuniyeti doğrudan etkileyen bu önemli ölçeklerin düşük çıkması, üreticilerin memnuniyet düzeylerinin yüksek olmadığı söylenebilir (Çizelge 3)

Yaşam Memnuniyetini Etkileyen Yargılar Üzerinde Faktör Analizinin Uygulanması

Bu araştırmada kırsal alanlarda yaşayan üreticilerin yaşam memnuniyeti, dünya mutluluk endeksinin kullandığı beşli likert ölçeği yargılarından faydalanarak, faktör analizi yardımı ile bulunmuştur. Mutluluk ile paralel olan yaşam memnuniyetini etkileyen 14 farklı değişken faktör analizi ile 4 ana faktöre indirgenmiştir. 1. faktör 5 değişken, 2. 3. ve 4. faktör üçer değişken olmak üzere toplam 14 değişkenden oluşur. Dört faktörün açıklayabildiği toplam varyans \%61.168 olarak saptanmıştır (Çizelge 4). Fiziksel ve ruhsal denge hali faktörünün yaşam memnuniyeti üzerindeki etki derecesi \%22.16'dır.

Tarımsal işletme sahiplerinde işletme ortalamasına göre üreticileri; kendilerini en çok ailelerinin mutlu ettiğini ifade edenlerin oranı \%66.70 bunu sırasıyla \%12.5 çocuklar, \%8.3 torunlar, \%5.2 eş, \%5.2 anne/baba ve \%2.1 kendisi takip etmektedir. Tarımsal işletme sahiplerinde genel olarak işletme ortalamasına göre mutluluk kaynağı olan değerlere bakıldığında; kendilerini en çok sağııklı olmanın mutlu ettiğini ifade edenlerin oranı \%60.4, \%11.5 başarı, \%10.4 sevgi, \%7.3 para, \%5.2 iş, \%3.1 güç ve \%2.1 diğerdir. Sağlıklı olmanın, üretici hayatında en önemli mutluluk kaynağı olduğu görülmektedir.

Üreticilerin Kamu Hizmetlerinden Memnuniyet Durumu Tarımsal işletme sahiplerinin kamu hizmetlerinden memnun olma durumuna bakıldığında; 3.04 ortalamayla 1. grup, 2.86 ortalamayla 2. grup, 3.40 ortalamayla 3. grup ve 2.86 ortalamayla 4. grup mevcut olup üreticilerin bu hizmetlerden memnun olmada fikirlerini beyan etmede "kararsız" kaldığı görülmektedir (Çizelge 5).

\section{Üreticilerin Tarım Politikalarından Memnuniyet Durumu}

Ele alınan tarımsal işletmelerde üreticilerin tarım politikasından memnun olma durumuna bakıldığında, yapılan analizler sonucunda tarımsal işletme ortalamasına göre üreticilerin, 2.66 ölçek ortalaması ile genel olarak tarım politikasından memnun olmadığı söylenilebilir (Çizelge, 6).

\section{Üreticilerin Umut ve Beklentileri}

Ele alınan tarımsal işletmelerde üreticilerin gelecekten beklenti ve/veya umut durumu ele alındığında, genel olarak tarımsal işletme ortalamasına göre üreticilerin gelecekten beklenti ve/veya umut düzeyi beşli likert ortalamasında 2.49'dur. Yapılan analizlere göre bu ortalama ile üreticilerin gelecekten beklenti ve umut düzeyinin düşük olduğu görülmektedir (Çizelge 7). 


\begin{tabular}{|c|c|c|c|c|c|}
\hline \multirow{3}{*}{$\begin{array}{l}\text { 1: Asla böyle hissetmiyorum 2: Nadiren hissediyorum 3: } \\
\text { Bazen böyle hissediyorum 4: Sık sık böyle hissediyorum 5: } \\
\text { Her zaman böyle hissediyorum }\end{array}$} & 1. Grup & 2. Grup & 3. Grup & 4. Grup & Genel \\
\hline & $(n=24)$ & $(n=24$ & $(n=24)$ & $(n=24)$ & $(n=96)$ \\
\hline & Ort & Ort & Ort & Ort & Ort \\
\hline \multirow[t]{2}{*}{ Hayatımdaki Amacımı Biliyorum } & 3.12 & 3.38 & 3.63 & 3.08 & 3.30 \\
\hline & $(0.99)$ & (1.09) & $(0.92)$ & $(1.06)$ & $(1.02)$ \\
\hline \multirow{2}{*}{$\begin{array}{l}\text { Yeni bir şey öğrenmede yetenek ve becerimi geliştirmede } \\
\text { heyecanlıyım }\end{array}$} & 3.08 & 2.88 & 3.50 & 3.04 & 3.13 \\
\hline & $(1.10)$ & (1.19) & $(0.88)$ & $(1.26)$ & $(1.12)$ \\
\hline \multirow[t]{2}{*}{ Hayatım fiziksel olarak dengede } & 3.00 & 2.96 & 3.58 & 3.17 & 3.18 \\
\hline & $(1.14)$ & $(1.30)$ & $(0.97)$ & $(1.04)$ & (1.13) \\
\hline \multirow[t]{2}{*}{ Hayatım duygusal olarak dengede } & 2.58 & 2.54 & 2.88 & 2.25 & 2.56 \\
\hline & $(1.01)$ & $(1.35)$ & $(1.07)$ & $(1.11)$ & (1.15) \\
\hline \multirow[t]{2}{*}{ Hayatım ruhsal olarak dengede } & 2.67 & 2.50 & 2.83 & 2.17 & 2.54 \\
\hline & $(1.09)$ & $(1.31)$ & (1.09) & $(1.09)$ & (1.14) \\
\hline \multirow{2}{*}{$\begin{array}{l}\text { Hayatım kontrol dışına çıktığı zaman düzene geçirmek için } \\
\text { sağlıklı davranışları tercih ederim }\end{array}$} & 2.75 & 2.42 & 2.92 & 2.71 & 2.70 \\
\hline & $(0.79)$ & $(0.17)$ & $(0.65)$ & $(0.80)$ & $(0.75)$ \\
\hline \multirow{2}{*}{$\begin{array}{l}\text { Ani durumlardan haberdar olmayı ve ani yaşamayı geçmiş ve } \\
\text { gelecek durumlara bakılmaksızın yaşamayı severim }\end{array}$} & 2.83 & 2.67 & 2.63 & 1.75 & 2.47 \\
\hline & $(1.20)$ & $(1.12)$ & $(1.40)$ & $(1.11)$ & $(1.27)$ \\
\hline \multirow[t]{2}{*}{ Aile ve arkadaşlarımla ilişkilerim var } & 4.00 & 4.00 & 4.04 & 3.96 & 4.00 \\
\hline & $(0.51)$ & $(0.51)$ & $(0.75)$ & $(0.62)$ & (0.59) \\
\hline \multirow[t]{2}{*}{ Hayatımda samimi ilişkilerim var } & 3.75 & 3.50 & 4.04 & 3.79 & 3.77 \\
\hline & $(0.67)$ & $(1.06)$ & $(0.62)$ & $(0.83)$ & $(0.82)$ \\
\hline \multirow{2}{*}{$\begin{array}{l}\text { Espri, mizah ve komiklik günlük hayatımın büyük bir } \\
\text { parçasıdır }\end{array}$} & 3.25 & 3.33 & 3.42 & 3.58 & 3.40 \\
\hline & $(1.18)$ & (1.16) & $(1.06)$ & $(1.10)$ & (1.11) \\
\hline \multirow[t]{2}{*}{ Ortaklığım adil ve dengelidir (iş ve kişisel) } & 3.17 & 3.67 & 3.46 & 3.17 & 3.36 \\
\hline & $(1.16)$ & $(0.96)$ & $(0.97)$ & $(0.86)$ & $(1.00)$ \\
\hline \multirow{2}{*}{$\begin{array}{l}\text { Stresle baş edebilmek için olumlu yolları tercih ederim } \\
\text { (egzersiz, konuşma vb.) }\end{array}$} & 3.29 & 3.04 & 3.21 & 3.08 & 3.16 \\
\hline & $(0.80)$ & $(0.69)$ & $(1.28)$ & $(0.58)$ & $(0.87)$ \\
\hline \multirow{2}{*}{$\begin{array}{l}\text { Hayatım boyunca yapabildiği şeyleri kontrol altına alamaya } \\
\text { çalışıyorum }\end{array}$} & 3.21 & 3.58 & 3.83 & 3.42 & 3.51 \\
\hline & $(0.97)$ & $(0.83)$ & $(0.70)$ & $(0.88)$ & $(0.87)$ \\
\hline \multirow[t]{2}{*}{ Hayatı şükrederek yaşıyorum } & 3.87 & 4.13 & 4.04 & 3.83 & 3.97 \\
\hline & $(0.85)$ & $(0.79)$ & $(0.85)$ & $(1.04)$ & $(0.88)$ \\
\hline \multirow[t]{2}{*}{ Hayatımı tutku (hırs) ve neşeyle yaşıyorum } & 2.96 & 3.00 & 3.33 & 2.79 & 3.02 \\
\hline & $(0.99)$ & $(1.02)$ & $(0.70)$ & (1.21) & $(1.00)$ \\
\hline \multirow{2}{*}{$\begin{array}{l}\text { Heyecan ve sabırsızlıkla geleceği, hayallerle tutkularla merak } \\
\text { ediyorum }\end{array}$} & 3.88 & 3.25 & 3.58 & 3.25 & 3.49 \\
\hline & $(0.94)$ & (1.26) & (1.41) & $(1.56)$ & $(1.32)$ \\
\hline \multirow[t]{2}{*}{ Ben iyimser biriyim } & 3.96 & 3.92 & 4.13 & 4.04 & 4.01 \\
\hline & $(0.69)$ & $(0.97)$ & $(0.44)$ & $(0.62)$ & $(0.70)$ \\
\hline \multirow{2}{*}{$\begin{array}{l}\text { Başkalarının görüşleri benimkinden farklı olsa bile } \\
\text { dinlemekten hoşlanırım }\end{array}$} & 3.50 & 3.96 & 4.00 & 4.00 & 3.86 \\
\hline & $(1.35)$ & (1.33) & $(0.88)$ & $(0.88)$ & (1.13) \\
\hline Biri beni kırdığı zaman onu affetmeyi kolay buluyorum & 2.96 & 2.63 & 2.71 & 2.50 & 2.70 \\
\hline & $(1.19)$ & $(1.17)$ & $(1.23)$ & $(1.38)$ & $(1.24)$ \\
\hline Başkasına zarar verdiğim zaman hızlıca düzeltip özür dilerim & 3.79 & 3.83 & 4.04 & 3.88 & 3.89 \\
\hline & $(0.65)$ & $(0.86)$ & $(0.62)$ & $(0.94)$ & $(0.78)$ \\
\hline Hayatımdaki olayları perspektif içinde tutma konusunda & 3.17 & 3.38 & 3.21 & 3.21 & 3.24 \\
\hline iyimserim & $(0.86)$ & $(0.92)$ & $(0.97)$ & $(0.58)$ & $(0.84)$ \\
\hline Tüm ilişkilerimde hayatımı doğru ve dürüstçe yaşıyorum & 3.50 & 3.38 & 3.88 & 3.42 & 3.54 \\
\hline & $(0.83)$ & (1.09) & $(0.68)$ & $(1.10)$ & $(0.95)$ \\
\hline Sevecenlik ve merhamet günlük olarak uyguladığım & 3.67 & 3.83 & 3.92 & 3.92 & 3.83 \\
\hline erdemlerdir & $(0.86)$ & $(0.76)$ & $(0.50)$ & $(0.71)$ & $(0.72)$ \\
\hline Her gün hizmet akımı yapıyorum & 3.25 & 3.00 & 3.54 & 3.42 & 3.30 \\
\hline & $(1.03)$ & $(1.10)$ & $(0.83)$ & $(0.71)$ & $(0.94)$ \\
\hline Hayatım boyunca beni koruyan ve besleyen güçlü bir & 4.08 & 3.54 & 4.13 & 4.08 & 3.96 \\
\hline inancım var & $(1.21)$ & $(1.41)$ & $(1.03)$ & $(0.83)$ & $(1.15)$ \\
\hline Genel Ortalama & 3.33 & 3.29 & 3.53 & 3.26 & 3.35 \\
\hline
\end{tabular}

(Parantez içindeki rakamlar standart sapma değerlerini vermektedir) 
Çizelge 4. Dört değişkene ilişkin faktör analizi sonuçları

\begin{tabular}{|c|c|c|c|c|c|}
\hline Yargılar & Ort & $\begin{array}{l}\text { Fiziksel ve } \\
\text { ruhsal } \\
\text { denge hali }\end{array}$ & $\begin{array}{l}\text { Sosyal } \\
\text { ilişkilerde } \\
\text { iyimserlik }\end{array}$ & $\begin{array}{l}\text { Hayatı sevme } \\
\text { ve olumlu } \\
\text { düşünme }\end{array}$ & $\begin{array}{l}\text { Şükretme } \\
\text { ve neşeli } \\
\text { olma }\end{array}$ \\
\hline (M4) Benim hayatım duygusal olarak(açıdan) dengeli & $\begin{array}{l}3.18 \\
(1.13)\end{array}$ & 0.916 & 0.105 & 0.147 & 0.153 \\
\hline (M5) Benim hayatım ruhsal olarak dengede & $\begin{array}{l}2.56 \\
(1.15)\end{array}$ & 0.905 & 0.091 & 0.180 & 0.161 \\
\hline (M3) Benim hayatım fiziksel olarak dengeli (dengede) & $\begin{array}{l}2.54 \\
(1.14)\end{array}$ & 0.734 & 0.158 & 0.295 & -0.003 \\
\hline $\begin{array}{l}\text { (M7) Ani durumlardan haberdar olmayı ve ani yaşamayı } \\
\text { geçmiş ve gelecek durumlara bakılmaksızın yaşamayı severim }\end{array}$ & $\begin{array}{l}2.70 \\
(0.75)\end{array}$ & 0.568 & 0.060 & 0.136 & 0.061 \\
\hline $\begin{array}{l}\text { (M6) Hayatım kontrol dışına çıktığı zaman yeniden düzene } \\
\text { geçirmek için sağlıklı davranışları tercihleri tercih ederim }\end{array}$ & $\begin{array}{l}2.47 \\
(1.27)\end{array}$ & 0.524 & 0.423 & 0.186 & 0.010 \\
\hline $\begin{array}{l}\text { (M18) Başkalarının görüşleri benimkinden farklı olsa bile } \\
\text { dinlemekten hoşlanırım }\end{array}$ & $\begin{array}{l}3.86 \\
(1.13)\end{array}$ & 0.157 & 0.753 & 0.041 & 0.018 \\
\hline (M17) Ben iyimser biriyim & $\begin{array}{l}4.01 \\
(0.70)\end{array}$ & 0.088 & 0.632 & 0.030 & 0.192 \\
\hline (M9) Hayatımda samimi ilişkilerim var & $\begin{array}{l}3.77 \\
(0.82)\end{array}$ & 0.267 & 0.465 & 0.342 & 0.205 \\
\hline (M24) Her gün hizmet akımı yapıyorum & $\begin{array}{l}3.30 \\
(0.94)\end{array}$ & 0.179 & -0.042 & 0.788 & 0.110 \\
\hline $\begin{array}{l}\text { (M23) Sevecenlik ve merhamet, günlük olarak uyguladığım } \\
\text { erdemlerdir. }\end{array}$ & $\begin{array}{l}3.83 \\
(0.72)\end{array}$ & 0.009 & 0.168 & 0.758 & 0.294 \\
\hline $\begin{array}{l}\text { (M12) Stresle baş edebilmek için olumlu yolları tercih } \\
\text { ederim(egzersiz, konuşma, meditasyon, vb.) }\end{array}$ & $\begin{array}{l}3.16 \\
(0.87)\end{array}$ & 0.117 & 0.396 & 0.472 & 0.052 \\
\hline $\begin{array}{l}\text { (M22) Tüm ilişkilerimde hayatımı doğru ve dürüstçe } \\
\text { yaşıyorum }\end{array}$ & $\begin{array}{l}3.54 \\
(0.95)\end{array}$ & 0.045 & 0.003 & 0.332 & 0.782 \\
\hline (M15) Hayatımı tutku (hırs) ve neşeyle yaşıyorum & $\begin{array}{l}3.02 \\
(1.00)\end{array}$ & 0.393 & 0.177 & 0.006 & 0.709 \\
\hline (M14) Hayatı şükrederek yaşıyorum & $\begin{array}{l}3.97 \\
(0.88)\end{array}$ & 0.055 & 0.552 & 0.089 & 0.578 \\
\hline \multicolumn{6}{|l|}{ Faktör Analizi Sonucu } \\
\hline Özdeğerler (eigenvalues) & & 4.597 & 1.751 & 1.203 & 1.016 \\
\hline Karesel yüklerin toplamı & & 3.104 & 1.932 & 1.850 & 1.682 \\
\hline Açıklanan varyans (\%) & & 22.169 & 13.802 & 13.212 & 12.015 \\
\hline Kümülatif varyans (\%) & & 22.169 & 35.971 & 49.183 & 61.198 \\
\hline
\end{tabular}

(Parantez içindeki rakamlar standart sapma değerlerini vermektedir)

Çizelge 5. Üreticilerin kamu hizmetlerinden memnuniyet durumu

\begin{tabular}{|c|c|c|c|c|c|}
\hline \multirow{3}{*}{$\begin{array}{l}\text { 1: Hiç memnun değilim 2: Memnun değilim 3: Kararsızım 4: } \\
\text { Memnunum 5: Çok Memnunum }\end{array}$} & 1. Grup & 2. Grup & 3. Grup & 4. Grup & Genel \\
\hline & $(n=24)$ & $(n=24)$ & $(n=24)$ & $(n=24)$ & $(n=96)$ \\
\hline & Ort & Ort & Ort & Ort & Ort \\
\hline \multirow[t]{2}{*}{ Sosyal güvenlik kurumu hizmetleri sizi memnun ediyor mu? } & 3.21 & 3.00 & 3.58 & 3.17 & 3.24 \\
\hline & $(1.10)$ & $(0.93)$ & $(0.88)$ & $(1.00)$ & (0.99) \\
\hline \multirow[t]{2}{*}{ Sağlık hizmetleri sizi memnun ediyor mu ? } & 3.42 & 3.29 & 3.63 & 3.08 & 3.35 \\
\hline & $(1.01)$ & $(0.95)$ & $(0.87)$ & $(1.21)$ & $(1.02)$ \\
\hline \multirow[t]{2}{*}{ Eğitim hizmetleri sizi memnun ediyor mu? } & 2.83 & 2.42 & 3.04 & 2.42 & 2.68 \\
\hline & $(1.04)$ & $(1.06)$ & $(1.04)$ & $(1.01)$ & $(1.06)$ \\
\hline \multirow[t]{2}{*}{ Adli hizmetler sizi memnun ediyor mu? } & 2.75 & 2.38 & 3.12 & 2.33 & 2.65 \\
\hline & $(0.98)$ & $(0.82)$ & $(0.79)$ & $(0.86)$ & $(0.91)$ \\
\hline \multirow[t]{2}{*}{ Asayiş hizmetleri sizi memnun ediyor mu? } & 3.21 & 3.00 & 3.42 & 3.17 & 3.20 \\
\hline & $(1.02)$ & $(0.83)$ & $(0.65)$ & $(1.00)$ & $(0.89)$ \\
\hline \multirow[t]{2}{*}{ Ulaştırma hizmetleri sizi memnun ediyor mu? } & 2.88 & 3.13 & 3.63 & 3.04 & 3.17 \\
\hline & (1.19) & $(0.94)$ & (0.64) & (0.99) & (0.99) \\
\hline Genel ortalama & 3.04 & 2.86 & 3.40 & 2.86 & 3.04 \\
\hline
\end{tabular}

(Parantez içindeki rakamlar standart sapma değerlerini vermektedir) 
Çizelge 6. Üreticilerin tarım politikalarından memnuniyet durumu

1: Hiç memnun değilim 2: Memnun değilim 3: Kararsızım 4:

Memnunum 5: Çok Memnunum

\begin{tabular}{lllll} 
1. Grup & 2. Grup & 3. Grup & 4. Grup & Genel \\
\hline$(n=24)$ & $(n=24)$ & $(n=24)$ & $(n=24)$ & $(n=96)$ \\
Ort & Ort & Ort & Ort & Ort \\
3.08 & 2.92 & 3.29 & 2.50 & 2.95 \\
$(1.01)$ & $(1.06)$ & $(0.90)$ & $(1.14)$ & $(1.06)$ \\
2.54 & 2.58 & 2.92 & 2.00 & 2.51 \\
$(1.10)$ & $(0.92)$ & $(1.01)$ & $(0.59)$ & $(0.97)$ \\
2.67 & 2.71 & 2.75 & 2.25 & 2.59 \\
$(1.09)$ & $(0.80)$ & $(1.03)$ & $(0.79)$ & $(0.94)$ \\
2.29 & 2.71 & 2.63 & 1.79 & 2.35 \\
$(1.04)$ & $(0.95)$ & $(0.97)$ & $(0.50)$ & $(0.95)$ \\
2.88 & 2.88 & 2.79 & 2.54 & 2.77 \\
$(1.07)$ & $(0.94)$ & $(0.83)$ & $(0.88)$ & $(0.93)$ \\
3.17 & 3.00 & 3.00 & 2.63 & 2.95 \\
$(1.16)$ & $(0.97)$ & $(1.02)$ & $(1.09)$ & $(1.07)$ \\
2.42 & 2.63 & 2.71 & 2.42 & 2.54 \\
$(0.77)$ & $(0.82)$ & $(0.90)$ & $(0.97)$ & $(0.87)$ \\
2.72 & 2.77 & 2.86 & 2.30 & 2.66
\end{tabular}

Genel Ortalama

(Parantez içindeki rakamlar standart sapma değerlerini vermektedir)

Çizelge 7. Üreticilerin gelecekten beklenti (umut) durumu beşli likert ortalamaları

1: Hiç umutlu değilim 2: Umutlu değilim 3: Kararsızım 4:

Umutluyum5: Çok Umutluyum

\begin{tabular}{lllll} 
1. Grup & 2. Grup & 3. Grup & 4. Grup & Genel \\
\hline$(n=24)$ & $(n=24)$ & $(n=24)$ & $(n=24)$ & $(n=96)$ \\
Ort & Ort & Ort & Ort & Ort \\
\hline 2.75 & 2.92 & 3.04 & 2.83 & 2.89 \\
$(1.07)$ & $(1.21)$ & $(1.08)$ & $(1.20)$ & $(1.13)$ \\
2.50 & 2.71 & 2.58 & 2.75 & 2.64 \\
$(1.02)$ & $(1.16)$ & $(0.88)$ & $(1.11)$ & $(1.03)$ \\
1.83 & 2.12 & 2.33 & 2.25 & 2.14 \\
$(0.63)$ & $(0.79)$ & $(0.81)$ & $(0.98)$ & $(0.82)$ \\
2.58 & 2.33 & 2.96 & 2.63 & 2.62 \\
$(1.10)$ & $(0.91)$ & $(1.04)$ & $(1.11)$ & $(1.05)$ \\
2.21 & 2.63 & 2.63 & 2.58 & 2.51 \\
$(0.88)$ & $(1.01)$ & $(1.20)$ & $(0.97)$ & $(1.02)$ \\
2.17 & 2.21 & 2.54 & 1.87 & 2.20 \\
$(0.86)$ & $(0.58)$ & $(1.14)$ & $(0.94)$ & $(0.92)$ \\
2.46 & 2.46 & 2.88 & 2.29 & 2.52 \\
$(0.93)$ & $(0.88)$ & $(1.11)$ & $(1.08)$ & $(1.01)$ \\
2.21 & 2.25 & 2.88 & 2.33 & 2.42 \\
$(0.88)$ & $(0.84)$ & $(1.07)$ & $(1.09)$ & $(1.00)$ \\
2.33 & 2.45 & 2.72 & 2.44 & 2.49
\end{tabular}

Gelecek yıllarda tarım topraklarında kimyasal ilaç ve güre

kullanmadan yüksek verim alacağınızdan umutlu musunuz?

Çiftçiliği değerlendirdiğimizde gelecekte çiftçilikten umutlu

musunuz?

2023 yılına kadar tarımsal işletme için yeni projeler

yapacağınızdan umutlu musunuz?

Tarım ve hayvancılık için yapılan politikalardan umutlu

musunuz?

Son 16 yılı değerlendirdiğimizde 2023 yılına kadar tarım sektöründe reform ve yenilikler olacağından umutlu musunuz?

2002 yılından 2018 yılına kadar politikaları değerlendirdiğimizde

ülkenin geleceğinden umutlu musunuz?

Genel ortalama

(Parantez içindeki rakamlar standart sapma değerlerini vermektedir)

Üreticilerin Ekonomik Gösterge ve Memnuniyet Durumu ile Memnuniyet Düzeyi Iliş̧ileri

Faktör analizi yardımı ile elde edilen dört ana faktör, yaşam memnuniyeti üzerindeki yarattığı \%61.198'lik etkinin, üreticilerin yaşam memnuniyetinin $\% 100$ 'ünü açıklayabilmek için yaşam memnuniyeti üzerinde etkili olan yargılar aşağıdaki Çizelge 8 'de yapılan hesaplama yoluyla üreticilerin yaşam memnuniyet düzeyi grupları belirlenmiştir.

Ele alınan tarımsal işletmelerde üretici yaşam memnuniyet düzey grupları, faktör analizi yardımıyla elde edilen dört ana yargı ve bu dört önemli yargıyı oluşturan 14 değişken geliştirilen ölçek yardımıyla (Çizelge 8-9) üç guruba ayrılmıştır. 1-3.02 arası ölçek düşük memnuniyet, 3.06-3.51 arası ölçek orta memnuniyet ve 3.56-5 arası ölçek yüksek yaşam memnuniyet düzeyini gösterir. Memnuniyet düzeyi 1-5 ölçeği arasında değişmekte olup üretici memnuniyetleri üç grup olarak bağımsız değişken özelliği göstermektedir (Çizelge 9). 
Çizelge 8. Faktör analiziyle belirlenen dört yargının yaşam memnuniyeti düzey gruplarını belirleme ölçeği

\begin{tabular}{llcc}
\hline Yargılar & Yaşam Memnuniyet Düzeyi Grupları Hesaplaması & \%Varyans & $\begin{array}{l}\text { Yaşam Memnuniyeti Açıklama } \\
\text { Ağırlıklandırması (\%100) }\end{array}$ \\
\hline 1. Faktör & $(\mathrm{M} 3+\mathrm{M} 4+\mathrm{M} 5+\mathrm{M} 6+\mathrm{M} 7) / 5 * 0.3622$ & 22.169 & $(22.169 * 100) / 61.198=0.3622$ \\
2. Faktör & $(\mathrm{M} 18+\mathrm{M} 17+\mathrm{M} 9) / 3 * 0.2255$ & 12.802 & $(12.802 * 100) / 61.198=0.2255$ \\
3. Faktör & $(\mathrm{M} 24+\mathrm{M} 23+\mathrm{M} 12) / 3 * 0.2159$ & 13.212 & $(13.212 * 100) / 61.198=0.2159$ \\
4. Faktör & $(\mathrm{M} 14+\mathrm{M} 15+\mathrm{M} 22) / 3 * 0.1963$ & 12.015 & $(12.015 * 100) / 61.198=0.1963$ \\
Toplam & & 61.198 & \\
\hline
\end{tabular}

Çizelge 9. Beşli likert ölçeğine göre yaşam memnuniyeti grupları

\begin{tabular}{lll}
\hline Yaşam Memnuniyet Grupları & Memnuniyet düzeyleri & Üretici sayısı \\
\hline Düşük Memnuniyet Düzeyi & $(1-3.02)$ & 32 \\
Orta Memnuniyet Düzeyi & $(3.06-3.51)$ & 32 \\
Yüksek Memnuniyet Düzeyi & $(3.56-5)$ & 32 \\
Toplam & $1-5$ & 96 \\
\hline
\end{tabular}

Üretim faktörlerinden biri olan sermaye, tarımsal işletmelerin sürdürülebilirliği için çok önemlidir. Genel olarak işletme başına düşen ortalama aktif sermaye 1 milyon 413 bin $524 \mathrm{TL}$, öz sermaye 1 milyon 138 bin 302 TL'dir. Tarımsal işletmelerde ortalama işletme başına düşen aktif sermayenin büyük bir payını toprak sermayesi oluşturmaktadır. Ele alınan tarımsal işletmelerde üretici yaşam memnuniyet düzey grupları, faktör analizi yardımıyla elde edilen dört ana yargı ve bu dört önemli yargıyı oluşturan 14 değişken, geliştirilen ölçek yardımıyla (Çizelge 8-9) üç guruba ayrılmıştır. Ele alınan tarımsal işletmelerin arazi genişliği ve bazı ekonomik göstergeleri ile tarımsal üreticilerin genel memnuniyet düzeyleri arasında farklılık olup olmadığını bulmak için Kruskall-Wallis analizinden yararlanılmıştır. Yapılan Kruskall-Wallis analizi sonucuna göre, seçilen ekonomik göstergeler ile yaşam memnuniyeti düzey grupları arasında anlamlı bir ilişki çıkmamıştır (Çizelge 10).

Insanların ekonomik zenginliği yansıtan arazi, bina, hayvan, alet-makine ve işletme sermayeleri gibi göstergeler yaşam memnuniyetine ulaşmada ve refaha ulaşmada çok önemli olduğu söylenebilir. Yaşam standardını belirleyen ve yakından ilgilendiren ekonomik göstergeler, bütün insanlar için öncelikli konuların başından geldiği söylenilebilir. Son zamanlarda, insanların yaşam memnuniyetini veya mutluluğunu da çok yakından etkileyen ekonomik sermaye göstergeleri, en önemli temel ihtiyaç haline gelmiştir. Insanlar arasında fakirlik ve yoksulluğun artması beraberinde mutsuzluğu da getirmektedir.

Seçilen ilçelerin yaşam memnuniyet düzeyi gurubu dağıımına bakıldığında; üç (Çine, Nazilli ve Söke) ilçenin memnuniyet düzeyi farklılık göstermektedir. Yapılan analizler sonucunda, Çine üreticilerinin $\% 16.5^{\prime} i$ düşük memnuniyet grubunda, \%53'ü yüksek memnuniyet grubunda yer alması, diğer iki ilçede yaşayan üreticilere göre memnun olanların oranı daha yüksek çıktığı tespit edilmiştir. ilçelerde yaşayan üreticiler arasındaki memnuniyet düzeyi, önemli bir fark yarattığında istatistiksel olarak önemlidir. Yapılan analize göre memnuniyet düzey grupları ile üreticilerin yaş sınırı (genç ve yaşlı üretici),

Çizelge 10. Ele alınan işletmelerin arazi genişliği ve bazı ekonomik göstergeleri ile işletme sahiplerinin genel memnuniyet düzey grupları

\begin{tabular}{lllll}
\hline & $\begin{array}{l}\text { Düşük Memnuniyet } \\
(\mathbf{n = 3 2 )}\end{array}$ & $\begin{array}{l}\text { Orta Memnuniyet } \\
(\mathbf{n = 3 2 )}\end{array}$ & $\begin{array}{l}\text { Yüksek Memnuniyet } \\
(\mathbf{n = 3 2 )}\end{array}$ & $\begin{array}{l}\text { Genel } \\
\mathbf{( 9 6 )}\end{array}$ \\
& $\mathbf{( 1 - 3 . 0 2 )}$ & $\mathbf{( 3 . 0 6 - 3 . 5 1 )}$ & $\mathbf{( 3 . 5 6 - 5 )}$ & \\
\hline \multirow{3}{*}{ Dekara Brüt Kâr (TL) } & Ort & Ort & Ort & Ort \\
& 2,774 & 3,892 & 2,262 & 2,976 \\
Bina Sermayesi (TL) & $(2,954)$ & $(3,855)$ & $(2,122)$ & $(3,104)$ \\
& 110,806 & 113,876 & 120,632 & 115,103 \\
Toplam İşletme Arazisi (da) & $(67,162)$ & $(89,069)$ & $(96,422)$ & $(84,330)$ \\
& 95,74 & 72,30 & 88,98 & 85,67 \\
Dekara Borç (TL) & $(81,41)$ & $(57,18)$ & $(66,69)$ & $(69,13)$ \\
& 794 & 949 & 413 & 719 \\
Değişken Masraflar (TL) & $(1,316)$ & $(1,733)$ & $(658)$ & $(1,200)$ \\
& 64,806 & 47,380 & 58,153 & 56,780 \\
Aktif Sermaye (TL) & $(76,629)$ & $(43,663)$ & $(46,968)$ & $(57,534)$ \\
& $1,671,226$ & $1,264,560$ & $1,304,786$ & $1,413,524$ \\
Öz Sermaye (TL) & $(1,392,249)$ & $(1,040,623)$ & $(881,394)$ & $(1,128,366)$ \\
& $1,266,396$ & $1,100,693$ & $1,047,817$ & $1,138,302$ \\
& $(784,424)$ & $(1,025,212)$ & $(773,474)$ & $(864,726)$ \\
\hline
\end{tabular}

(Parantez içindeki rakamlar standart sapma değerlerini vermektedir) 
eğitim (ilköğretim ve diğer tahsiller), çiftçilik deneyim durumu ve hayvancılık yapma durumu gibi kategorik değişkenler arasında istatistiksel olarak önemli bir ilişki çıkmamıştır (Çizelge, 11).

\section{TARTIŞMA VE SONUÇ}

$\mathrm{Bu}$ araştırmada, kırsal alanlarda tarımla uğraşan üreticilerin sosyo ekonomik özellikleri ve yaşam memnuniyet düzeyi belirlenmiş olup ekonomik sermaye ve memnuniyet düzeyi arasındaki ilişki tespit edilmiştir.

İşletme yöneticisinin kişisel niteliklerinin veya sosyal özelliklerinin, işletmelerin yönetim biçimi, organizasyonu, teknolojik yenilikleri benimseme ve uygulaması gibi tüm işletme faktörleri üzerine etkisi olduğu belirtilmektedir (Esengün, 1990). Kırsal alanlarda tarımsal işletmecilik ve üretimin istikrarlı bir şekilde yürütülebilmesi için yetkili merciler tarafından, üreticilerin genel özelliklerinin iyi benimsenmesi ve çözüm odaklı politikalar uygulanması, olumlu bir etki yaratacaktır.

$\mathrm{Bu}$ araştırmada, tarımsal işletme ortalamasına göre üreticilerin \%72.9'u ilköğretim mezunu, \%27.1'i lise ve yüksekokul mezunudur. Genel olarak işletme başına düşen ortalama sermaye varlığı 1 milyon 413 bin 524 TL'dir. Tarımsal işletmeler için sermaye miktarının yüksek olması, işletmeyi daha modern üretime kavuşturabilme özelliği kazandırıp, üretici memnuniyetini olumlu yönde etkileyebilir. İşletme ortalamasına göre, üreticilerin mutluluk ölçeği ortalaması 3.35'tir. Ekonomik sermayesi yüksek olan üreticilerin mutluluk ölçeği, ekonomik sermayesi düşük olan üreticilerin mutluluk ölçeğinden daha düşük çıkmıştır. Peru'da, Mateu ve ark. (2020) en yoksul beş bölgede yaptıkları bir araştırmada, mutluluk ve yoksulluk arasında negatif bir ilişki olduğunu ve bu yoksul bölgelerdeki ev sahiplerinin \%66'sının mutsuz olduğunu tespit etmişlerdir. Katipoğlu ve Armağan (2020) Aydın'da
ASLAN F, ARMAĞAN G

yaptıkları bir araştırmada, bazı beşeri ve sosyal sermaye göstergelerinin kırsal kalkınmada önemli olduğu sonucuna varmışlardır. Keleş ve ark. (2018) Erzurum'da yapmış oldukları araştırmada, Kırsal alanda sosyal sermaye ile yaşam memnuniyeti arasında pozitif yönlü bir ilişkinin olduğunu bulmuşlardır. Yapılan bu araştırmalar değerlendirildiğinde; sosyal, beşeri ve ekonomik sermaye gibi önemli göstergelerinin kırsal alan ve kalkınmada yaşam memnuniyetini etkilediği söylenebilir.

$\mathrm{Bu}$ araştırmada; kırsal alanlarda yaşayan üreticilerin memnuniyeti üzerinde etkili olan önemli dört ana faktör; fiziksel denge hali, ruhsal denge hali, sosyal ilişkilerde iyimserlik ve hayatı sevme-olumlu düşünme faktörleridir. Özellikle kırsal alanlarda yaşayan üreticilere yönelik, yaşam memnuniyeti ve sosyo ekonomik özelliklerini belirlemeye yönelik çalışmaların yapılması sürdürülebilir kırsal kalkınma ve gıda açısından olumlu yeni gelişmeler meydana getirebilir.

Bu araştırmada; işletme ortalamasına göre üreticilerin kamu hizmetlerinden memnun olma durumu 3.04 ortalama ile kamu hizmetlerinden memnuniyet durumunda fikirlerini beyan etmede kararsız kalmışlardır. Tarım politikasından memnuniyet durumu işletme ortalamasına göre, üreticilerin, 2.66 ölçek ile tarım politikasından memnuniyet düzeyinin düşük çıktığı söylenilebilir. Tarımsal işletme ortalamasına göre üreticilerin gelecekten beklenti ve/veya umut düzeyi ölçeği 2.49 olarak tespit edilmiştir. Bu sonuçlara göre, üreticilerin gelecekten beklenti ve umutlu olma durumunun düşük olduğu görülmektedir. Tarımsal üretimin sürekliliği, besin ihtiyacının karşılanabilmesi, kırsal alanlardan kentsel alanlara göçün önüne geçilebilmesi için politikacıların tarımsal üreticilere yönelik istikrarlı politikalar yürütmesi, üretici memnuniyet düzeyini artırabileceği söylenilebilir.

Çizelge 11. Memnuniyet düzeylerinin ilçelere göre ve üreticilerin bazı özelliklerine göre dağılımı

\begin{tabular}{|c|c|c|c|c|c|c|c|c|c|}
\hline & \multicolumn{2}{|c|}{$\begin{array}{l}\text { Düşük } \\
\text { Memnuniyet } \\
(1-3.02) \\
(n=32)\end{array}$} & \multicolumn{2}{|c|}{$\begin{array}{l}\text { Orta } \\
\text { Memnuniyet } \\
(3.06-3.51) \\
(n=32)\end{array}$} & \multicolumn{2}{|c|}{$\begin{array}{l}\text { Yüksek } \\
\text { Memnuniyet } \\
(3.56-5) \\
(n=32)\end{array}$} & \multicolumn{2}{|c|}{$\begin{array}{l}\text { Genel } \\
(1-5) \\
(n=96)\end{array}$} & \multirow[t]{2}{*}{$\begin{array}{l}\text { Hesaplanan } \\
\text { Khi Kare } \\
\text { Değeri }\end{array}$} \\
\hline & Kişi & $\%$ & Kişi & $\%$ & Kişi & $\%$ & Kişi & $\%$ & \\
\hline \multicolumn{10}{|l|}{ İlçe } \\
\hline Çine & 5 & 16.50 & 10 & 31.30 & 17 & 53.10 & 32 & 100.00 & \multirow{3}{*}{$11.063 *$} \\
\hline Nazilli & 15 & 46.90 & 11 & 34.40 & 6 & 18.80 & 32 & 100.00 & \\
\hline Söke & 12 & 37.50 & 11 & 34.40 & 9 & 28.10 & 32 & 100.00 & \\
\hline \multicolumn{10}{|l|}{ Yaş } \\
\hline Genç Üretici (22-50) & 11 & 23.90 & 18 & 39.10 & 17 & 37.00 & 56 & 100.00 & \multirow[t]{2}{*}{3.509} \\
\hline Yaşlı Üretici (51+) & 21 & 42.00 & 14 & 28.00 & 15 & 30.00 & 50 & 100.00 & \\
\hline \multicolumn{10}{|l|}{ Eğitim } \\
\hline Illköğretim & 25 & 35.70 & 23 & 23.90 & 22 & 31.40 & 70 & 100.00 & \multirow[t]{2}{*}{0.738} \\
\hline Diğer tahsiller & 7 & 26.90 & 9 & 34.60 & 10 & 38.50 & 26 & 100.00 & \\
\hline \multicolumn{10}{|c|}{ Çiftçilik Deneyim Durumu } \\
\hline$(0-25)$ & 17 & 30.90 & 21 & 38.20 & 17 & 30.90 & 55 & 100.00 & \multirow[t]{2}{*}{1.362} \\
\hline$(26-57)$ & 15 & 36.60 & 11 & 26.80 & 15 & 36.60 & 41 & 100.00 & \\
\hline \multicolumn{10}{|c|}{ Hayvancılık Yapma Durumu } \\
\hline Hayır & 15 & 45.50 & 10 & 27.00 & 12 & 32.40 & 37 & 100.00 & \multirow[t]{2}{*}{1.671} \\
\hline Evet & 17 & 28.80 & 22 & 37.30 & 20 & 33.90 & 59 & 100.00 & \\
\hline
\end{tabular}

: $p<0,05$ düzeyinde önemli 
Üreticilerin sosyo ekonomik durumları ve yaşam memnuniyetini etkileyen faktörler dikkate alınarak geliştirilen ölçekle, üretici yaşam memnuniyet düzey grupları üçe gruba ayrılmıştır. 1-3.02 ölçek aralığı düşük memnuniyet, 3.06-3.51 ölçek aralığı orta memnuniyet ve 3.56-5 aralığı yüksek memnuniyet düzey grubunu göstermektedir. Bu araştırmada üreticilerin yaşam memnuniyet düzeyi farklı analizlerle belirlenirken, yaşam memnuniyeti üzerinde etkili olan birbirinden farklı değişken ve ekonomik konulardan faydalanılmıştır. Özellikle günümüz toplumlarında, "ekonomik sermayesi fazla yani parası çok olan insanlar yaşamdan daha çok mutlular" anlayışı, üreticiler üzerinde farklı test ve analizler uygulandığında bu anlayışın her zaman doğru olmadığı sonucu tespit edilmiştir. Tarımsal işletmelerde, ekonomik sermayesi ve parası çok olan üretici gruplarının çok mutlu olmadığını, ekonomik sermayesi az olan üreticilerin de mutsuz olmadığı, mutluluk ve para (ekonomik sermaye) arasındaki ilişkinin ise istatistiki açıdan önemli çıkmadığı sonucuna varılmıştır.

Bilindiği üzere insanların gıda ihtiyacını karşılayan tarımsal üretimin önemli bir kısmı kırsal alanlarda yapılmaktadır. Sürdürülebilir kırsal kalkınma-alan, tarımsal üretim ve gıda için "Butan hükümetinin ülkesinde uyguladığı kişi başına düşen mutluluğu artırma" politikasının istikrarlı bir şekilde hayata geçmesi, Türkiye ve bütün dünya için yeni bir reform olacağı söylenebilir.

\section{TEŞEKKÜR}

$\mathrm{Bu}$ projenin yürütülmesinde Aydın Adnan Menderes Üniversitesi Bilimsel Araştırma Projeleri biriminin (ZRF18018 nolu proje), vermiş olduğu mali desteklemelerinden dolayı teşekkür ederiz.

\section{KAYNAKLAR}

Armagan G, Walley K, Custance P Rural (2012) Development and the Role of Farmers: Peasants, Producers and Entrepreneurs. 3rd Moravian Conference on Rural Research, 12:3-7, Mendel University.

Easterlin R (1974) "Does Economic Growth Improve the Human Lot?" in Paul A. David and Melvin W. Reder, eds., Nations and Households in Economic Growth. 2(22) 89-125.

Esengün K (1990) Tokat illinde Meyve Yetiştiriciliği Yapan İşletmelerin Ekonomik Durumu ve İşletme Sonuçlarını Etkileyen Faktörlerin Değerlendirilmesi Üzerine Bir Araştırma. Doktora Tezi, Ege Üniversitesi Fen Bilimleri Enstitüsü, İzmir.

IIlhan S (2006) Kobi'ler Sosyo-Ekonomik Bir Perspektif. Fırat Üniversitesi Sosyal Bilimler Dergisi, (16)2: 269-289.

Katipoğlu P, Armağan G (2020) Tarımda Beşeri ve Sosyal Sermayenin Kırsal Kalkınmada Önemi. İzmir İktisat Dergisi, (35)1: 155-175.

Kahneman D, Deaton A (2012) High Income Improves Evaluation of Life But Not Emotional Well-being. Center for Health and Well-being, Princeton University, 38(7): 1-5.

Keleş Ş, Keskin A, Ertek N (2018) Kırsal Alanda Sosyal Sermayenin Yaşam Memnuniyeti Üzerine Etkisi. Kahramanmaraş Sütçü İmam Üniversitesi Tarım ve Doğa Dergisi, 21: 123-132.

Newbold P (1995) Statistics for Business and Economics. USA.

Mateu P, Vasquez E, Zuniga J, Ibanez F (2020) Happiness and Poverty in the Very Poor Peru: Measurement Improvements and a Consistent Relationship. Journal of the Springer Nature, 54: 1075-1094

TÜik (2013) Yaşam Memnuniyeti Araştırması. http://tuik.gov.tr/PreHaberBultenleri.do?id=18629. Erişim Tarihi: 01.02.2018.

Şeker M (2010) Mutluluk Ekonomisi. Journal of Economy Culture and Society, (0) 39: 115-140.

Ura K, Alkire S, Zangmo T, Wangdi K (2012) An Extensive Analysis of GNH Index Centre for Bhutan Studies. Thimphu, Bhutan.

World Happines Center https://www.thehappinesscenter.com/happinesssurvey. Erişim Tarihi: 11.11.2018 